\title{
Food bodies and their significance for obligate ant-association in the tree genus Macaranga (Euphorbiaceae)
}

\author{
BRIGITTE FIALA \\ Zoologisches Institut III der Universität Würzburg, Biozentrum, Am Hubland, D-8700 \\ Würzburg, Federal Republic of Germany
}

AND

\section{ULRICH MASCHWITZ}

Zoologisches Institute, 7. W.-Goethe-Universität, Siesmayerstr. 70, D-6000 Frankfurt, Federal Republic of Germany

FIALA, B. \& MASCHWITZ, U., 1992. Food bodies and their significance for obligate ant-association in the tree genus Macaranga (Euphorbiaceae). The production of extrafloral nectar and food bodies plays an important role in many tropical ant-plant mutualisms. In Malaysia, a close association exists between ants and some species of the pioneer tree genus Macaranga (Euphorbiaceae). Macaranga is a very diverse genus which exhibits all stages of interaction with ants, from facultative to obligatory associations. The ants nest inside the hollow internodes and feed mainly on food bodies provided by the plants. Food body production had previously been reported only in myrmecophytic Macaranga species, where it is usually concentrated on protected parts of the plants such as recurved stipules. We found that non-myrmecophytic Macaranga species also produce food bodies on leaves and stems, where they are collected by a variety of ants. Levels of food body production differ between facultatively and obligatorily ant-associated species but also among the various non-myrmecophytes. This may be related to the degree of interaction with ants. Food body production starts at a younger age in the myrmecophytic species than in the transitional or non-myrmeccophytic Macaranga. Although food bodies of the non-inhabited Macaranga species are collected by a variety of ants, there is no evidence of association with specific ant species. Our observations suggest that food bodies enhance the evolution of ant-plant interactions. Production of food bodics alone, however, does not appear to be the most important factor for the development of obligate myrmecophytism in Macaranga.

ADDITIONAL KEY WORDS: - Ant-plant interactions - evolution - food bodies - Macaranga -Malaysia - myrmecophytism.

\section{CONIENTS}

Introduction

Material and methods.

Results

Myrmecophytic Macaranga species .

Non-myrmecophytic Macaranga species. 
Discussion .

Contents of food bodies

Production rates

Localization

Function

Food bodies and the evolution of myrmecophytism .

Acknowledgements

References

\section{INTRODUCIIION}

Food bodies belong to a large category of structures, collectively called pearl bodies, and include a variety of small epidermal and subepidermal structures with diverse shapes. They range from single cells to multicellular bodies (O'Dowd, 1982) and are characterized by a pearl-like lustre. Some authors restrict the term "food bodies" to highly specialized ant-plant associations where they play an essential role as ant food (review e.g. in Buckley, 1982; Beattie, 1985). Keeler (1989) does not differentiate between the terms food bodies and pearl bodies. Earlier, Rickson \& Risch (1984) considered the two terms to be different, but in recent transmission electron microscope studies found them to be similar structurally (Rickson, personal communication). We regard the terms as synonymous.

Pearl bodies occur over a wide range of taxa in the Dicotyledonae and have been described from leaves, shoots and stems of 50 genera in 19 families (O'Dowd, 1982), all tropical or subtropical. As with extrafloral nectaries (EFN), they have long been hypothesized to attract ants and function as ant food (Penzig, 1982), although collection of pearl bodies by insects has so far been directly observed only in relatively few plants species (e.g. Raciborski, 1898 1900). In highly specialized ant-plant associations, however, food bodies are an essential part of the ants' diet.

Ultrastructure and development of some myrmecophyte food bodies have been described. They contain carbohydrates, lipids and proteins (O'Dowd, 1982), and can thus offer a nutrient supply complementary to EFN-secretions or honeydew.

In S.E. Asia, several species of the tree genus Macaranga Thou. (Euphorbiaceae) live in close relationship with ants. The genus comprises a full range of species from those not inhabited by ants to obligate myrmecophytes. Non-myrmecophytes are, however, visited by various ant species. Five clear species groups (sections) can be recognized, some further species are individually distinctive (Whitmore, 1973, 1975, 1982). In Peninsular Malaysia, nine of 27 Macaranga species occurring mostly in pioneer habitats are obligate myrmecophytes usually inhabited by Crematogaster ants, mainly C. borneensis, which is dependent on its host plant for survival (Fiala, 1988; Fiala \& Maschwitz, 1990). The ants protect their host plants against herbivores and competing vegetation, especially vines (Fiala el al., 1989, 1991). The ants nest in the hollow stems of the Macaranga trees and feed exclusively on food bodies produced by the plants (Beccarian bodies, Rickson, 1980) and honeydew from scale insects cultivated inside the stems (Fiala \& Maschwitz, 1990).

The offer of nesting space is one important predisposition for interactions with ants in the genus Macaranga (Fiala \& Maschwitz, 1992), supply of food another possible ant-attractant. However, the presence of EFN does not seem to be an 
essential feature in the evolution of obligate myrmecophytism in that genus (Fiala \& Maschwitz, 1991). We, therefore, investigated the production of food bodies as another possible predisposition in the evolution of such symbioses. Here we present data on the distribution of food bodies in the genus Macaranga in Peninsular Malaysia.

\section{MATERIAL AND METHODS}

The study was carried out from 1985 to 1990 , covering a total of 16 months in various parts of the Malay Peninsula. More than 1000 plants of 23 Macaranga species were studied, mainly in secondary habitats. All plants were surveyed along transects about $2 \mathrm{~km}$ long (20-50 specimens per species from different locations).

In the field we investigated the plant surfaces for the presence of pearl bodies. Whenever possible, we collected material for examination with a dissecting microscope. For comparison we also looked for food bodies in the closely related genus Mallotus Lour. We recorded the presence of ants and gathered information on the degree of association with the plants.

Five myrmecophytic and three non-myrmecophytic Macaranga species were grown in the greenhouse at Frankfurt. For scanning electron microscopy (SEM) we used fresh leaf material on a Hitachi Type S 500. Preliminary tests on food body contents were carried out with Merckotests for lipids (available from MERCK) and the anthrone method of Mokrasch (1954) for carbohydrates. Identification of Macaranga and specific classification followed Whitmore (1967, 1973, 1975). Voucher specimens are held by B.F. and the herbarium of the Forest Research Institute Malaysia, Kepong.

\section{RESULTS}

\section{Myrmecophytic Macaranga species}

All myrmecophytic Macaranga species develop epidermal structures of two types: large Beccarian bodies, concentrated in different locations which are species-specific, and smaller food bodies scattered over leaf and stem surface. Almost all myrmecophytic members of the section Pachyslemon sensu stricto (Table 1) produce the Beccarian bodies on the abaxial surface of recurved stipules: M. constricta Whitmore \& Airy Shaw, M. hullettii King ex Hook. fi., M. kingii Hook. fi., M. molleyana subsp. grifflthiana (Muell. Arg.) Whitmore, and M. triloba (Bl.) Muell. Arg. (Fig. 1). An exception is M. hypoleuca Muell. Arg., where many Beccarian bodies develop on the abaxial surface of the leaves (Fig. 2). The two West-Malaysian species of the section pruinosa, M. pruinosa (Miq.) Muell. Arg. and M. hosei King ex Hook. f. as well as one species from Pachystemon Sensu lato, M. caladiifolia Becc. ( = M. puncticulata Gage, Whitmore, 1975) produce them on the adaxial surface of horizontal or upward turned stipules (Fig. 3). Many food bodies were also produced on the floral bracts of female inflorescences in $M$. triloba (Fig. 4) and $M$. hulletlii, but not in $M$. heynei I. M. Johnston or M. tanarius (L.) Muell. Arg. (no data are available for other species because these were not flowering during the study period).

So far we have found four different forms of Cremalogaster associated with these myrmecophytic Macaranga species, all belonging to the subgenus Decacrema. 
Table 1. Presence of food bodies in Macaranga species studied in Peninsular Malaysia; relative numbers of food bodies: $+(\mathrm{few},<50)$ to $+++($ many, $>500),(+)=$ only rarely

\begin{tabular}{|c|c|c|}
\hline \multirow[b]{2}{*}{ Species } & \multicolumn{2}{|c|}{ Abundance of food bodies } \\
\hline & Per stipule & Per leaf surface \\
\hline \multicolumn{3}{|l|}{ MYRMECOPHYTES } \\
\hline M. constricta & ++ & + \\
\hline M. hulletii & +++ & + \\
\hline M. hypoleuca & $(+)$ & +++ \\
\hline & Stipules not persistent & Lower surface \\
\hline M. kingii & ++ & + \\
\hline M. motleyana ssp. griffithiana & +++ & + \\
\hline M. triloba & +++ & + \\
\hline \multicolumn{3}{|l|}{ 'TRANSITIONALS' } \\
\hline $\begin{array}{l}\text { M. caladiifolia } \\
(=\mathrm{M} \text {. puncticulata) }\end{array}$ & + & + \\
\hline \multicolumn{3}{|l|}{ pruinosa-group } \\
\hline M. hosei & ++ & + \\
\hline M. pruinosa & + & + \\
\hline \multicolumn{3}{|c|}{ NON-MYRMECOPHYTES } \\
\hline M. quadricornis & ? & + \\
\hline M. recurvata & + & + \\
\hline \multicolumn{3}{|l|}{ Section Pachystemon sensu lato } \\
\hline M. curtisii & $\begin{array}{c}(+) \\
\text { Stipules not persistent }\end{array}$ & + \\
\hline M. curtisii var. glabra & $(+)$ & + \\
\hline \multicolumn{3}{|l|}{ Section Stachyella } \\
\hline M. amissa & $(+)$ & $(+)$ \\
\hline M. conifera & $(+)$ & + \\
\hline \multicolumn{3}{|l|}{ Section Pseudo-Rottlera } \\
\hline M. lowii & Stipules hair-like & + \\
\hline $\begin{array}{l}\text { Section Javanicae } \\
\text { M. heynei }\end{array}$ & Section Javanicae & + \\
\hline \multicolumn{3}{|l|}{ Individually distinctive } \\
\hline$M$. denticulata & Stipules not persistent & + \\
\hline M. diepenhorstii & - & + \\
\hline M. gigantea & + & + \\
\hline$M$. indica & $(+)$ & + \\
\hline M. tanarius & Stipules not persistent & ++ \\
\hline M. trichocarpa & $(+)$ & + \\
\hline
\end{tabular}

Species from the C. borneensis group are dominant but these ants are so variable that probably a few more species (subspecies?) may be involved in what is so far called C. borneensis (J. Longino, personal communication). The species taxonomy remains preliminary since Crematogaster is a very large genus which needs taxonomic revision. We have evidence so far for some Crematogaster being restricted to certain Macaranga species, for instance we find a preference for M. hypoleuca in C. decamera. Since C. borneensis was the most abundant ant in the myrmecophytic specimens studied, we will restrict our discussion to this species although we did not recognize behavioural differences in the other as yet undescribed Cremalogaster spp. on Macaranga. 


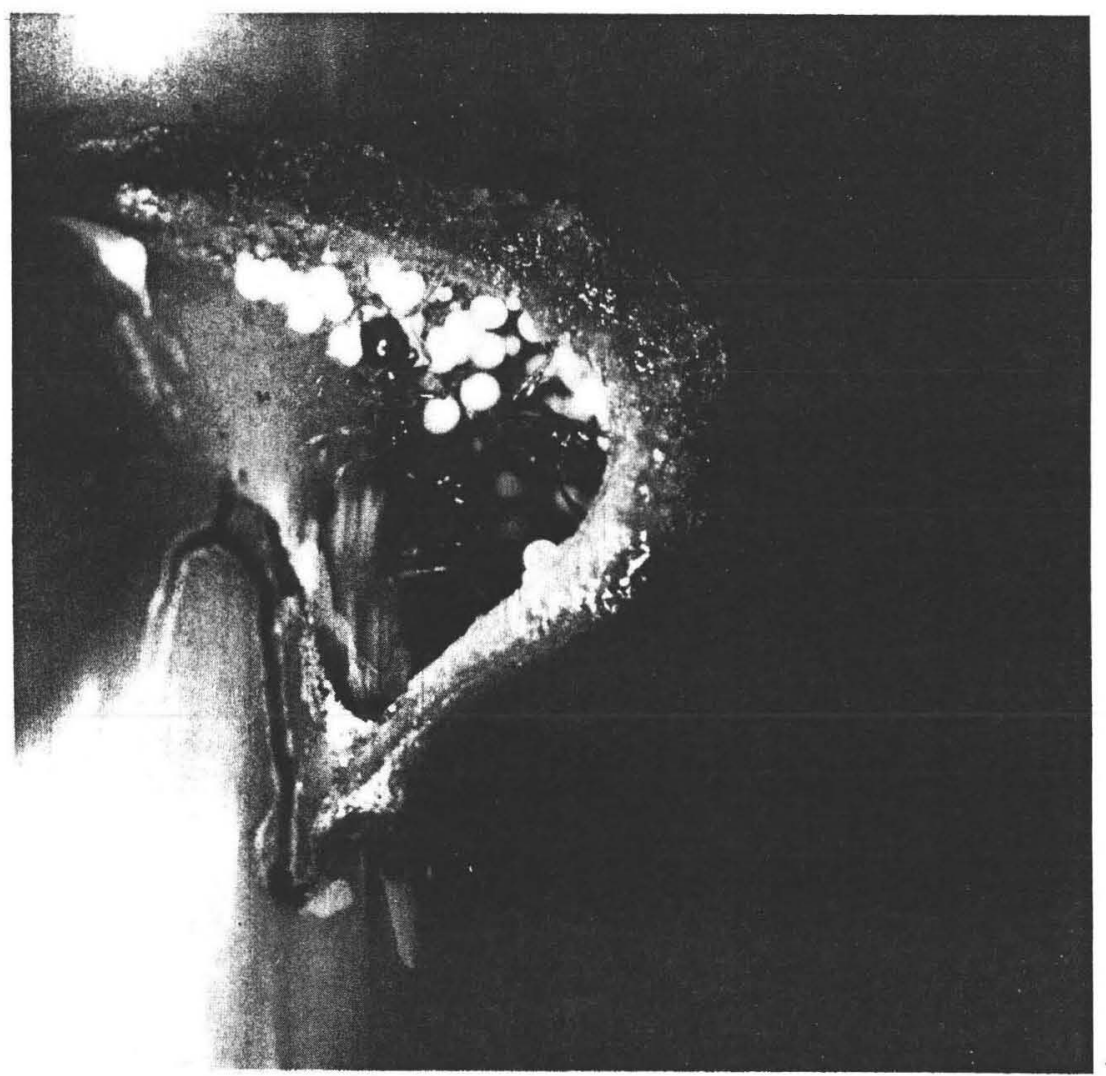

Figure 1. Ants collecting food bodies produced under recurved stipules of $M$. triloba $(\times 7)$

Production of food bodies on myrmecophytic Macaranga species was easy to demonstrate. Food bodies were always present under stipules, especially in earlier stages of development since C. borneensis ants collect mainly the larger, fully developed ones. Macaranga of the pruinosa group, however, seem to produce fewer food bodies that those in Pachystemon sensu stricto (cf. M. hosei, Tables 1 and 2 ). In the field only few $(<30)$ food bodies were found on the stipules of $M$. pruinosa. However, even fewer were seen on those of $M$. caladiffolia (section Pachystemon sensu lato). We regard all three species as transitional between noninhabited forms and obligate myrmecophytes since the frequency of ant colonization of them is lower than in the latter.

Food body production begins at an early stage of plant development, e.g. in saplings of $M$. triloba $(\mathcal{N}=51), M$. hullellii $(\mathcal{N}=31)$ and $M$. hypoleuca $(\mathcal{N}=28)$ from a height of only $9 \mathrm{~cm}$ (percentage of plant size with food bodies: $8 \mathrm{~cm}$ and $9 \mathrm{~cm}: 50 \%(\mathcal{N}=20), 9-13 \mathrm{~cm}: 75 \%(\mathcal{N}=40),>13 \mathrm{~cm}: 100 \%(\mathcal{N}=50)$. The earliest food bodies were present at the third set of stipules (between the third and fourth internode), although on average, they were not produced until the development of the sixth internode (average height about $13 \mathrm{~cm}$ ). This is 


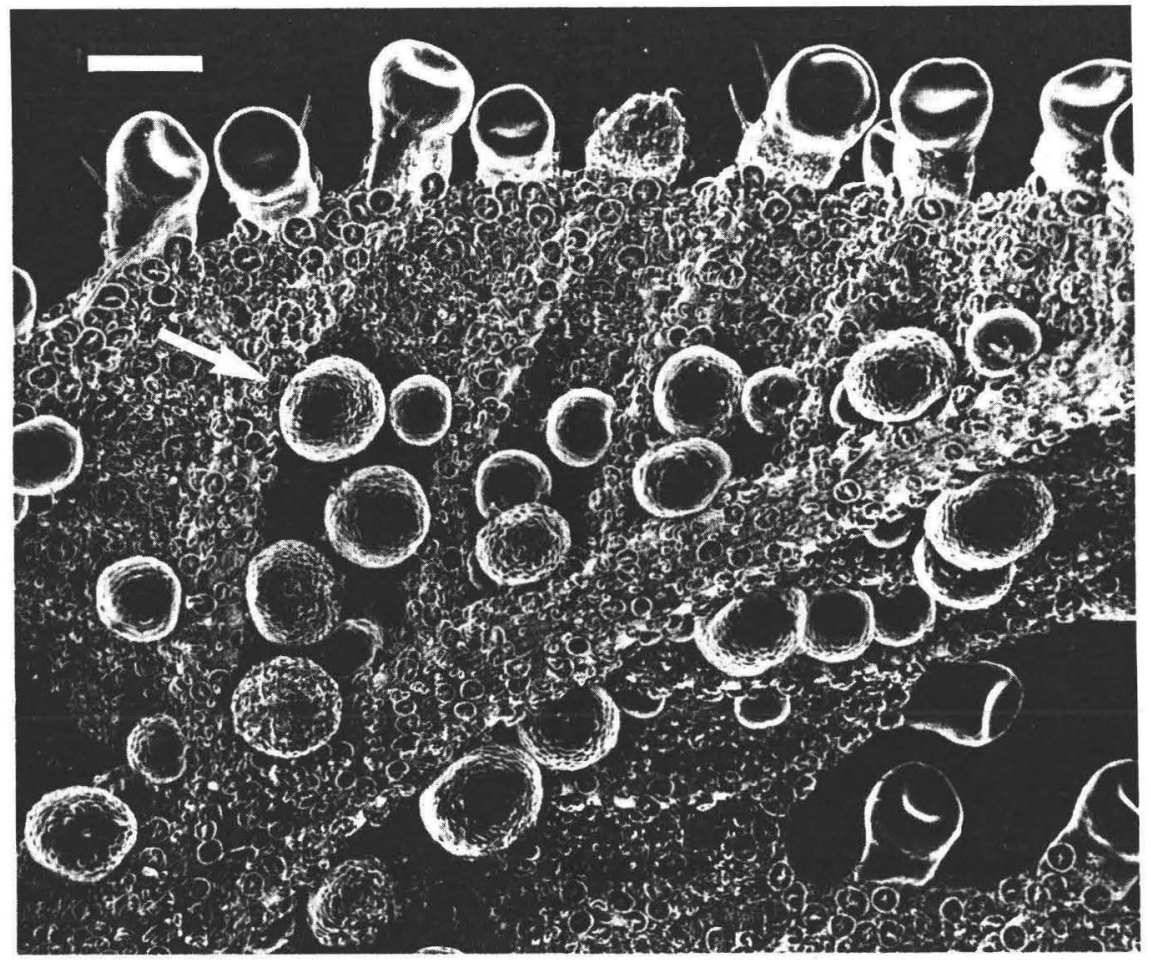

Figure 2. SEM of lower leaf surface of $M$. hypoleuca. Food bodies on lamina (arrow) and glands at margin of a young leaf (scale bar $=500 \mu \mathrm{m})$.

approximately the same size at which plants start to be colonized by $C$. borneensis, although rarely queens colonized plants which had not yet produced food bodies (four times in our sample). Among the investigated myrmecophytic species we found no differences in plant size at which food body production started. In the

TABLE 2. Comparison of number of food bodies produced on different Macaranga species in the greenhouse (range of $\mathcal{N}=5$ plants each)

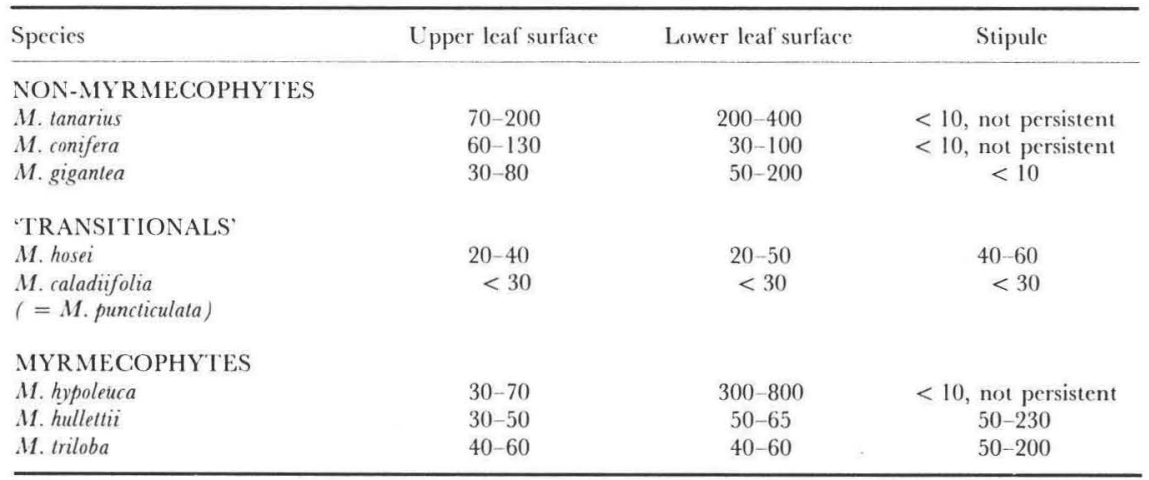



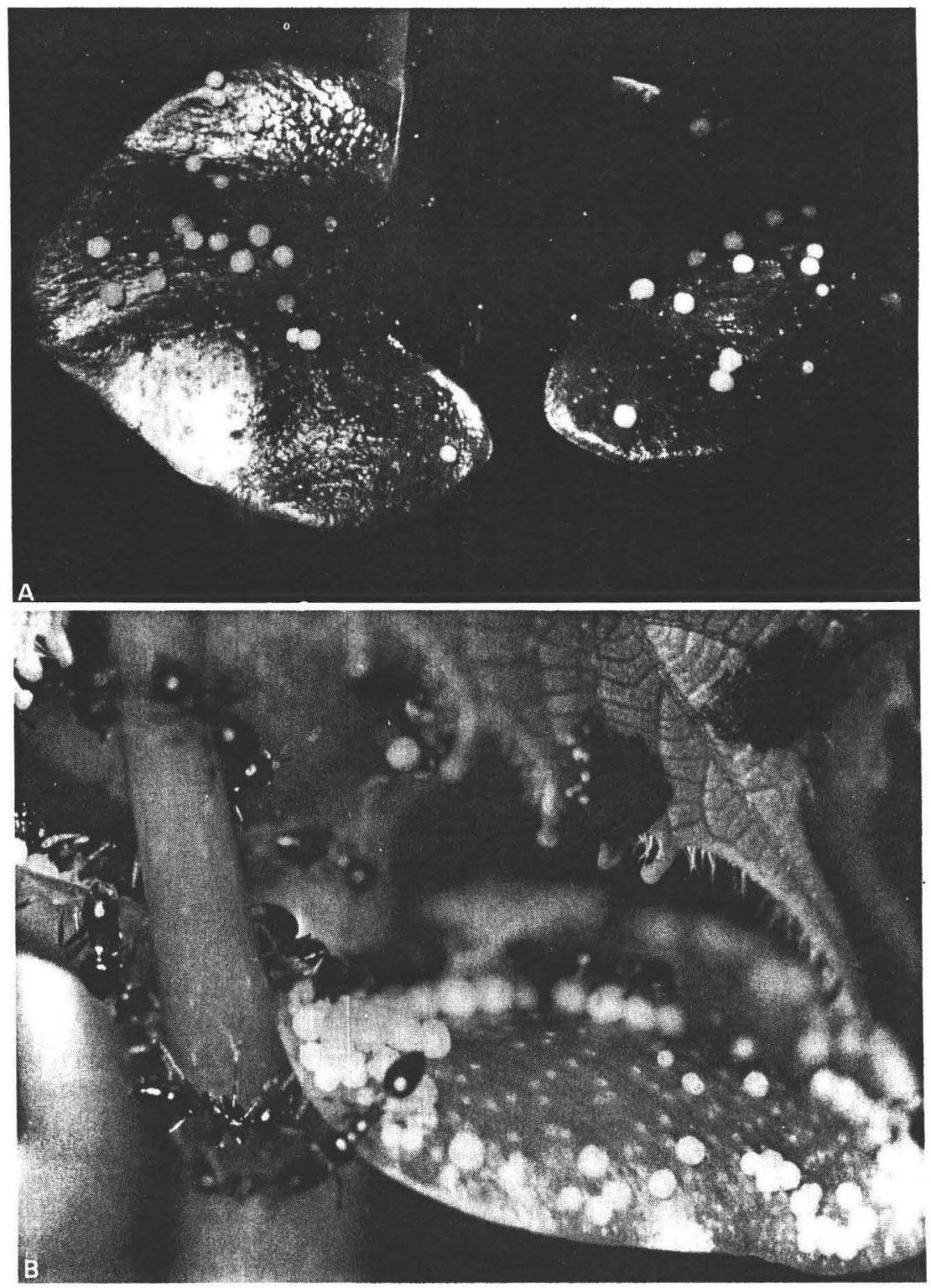

Figure 3. A, B, Food bodies on stipules of $M$. hosei ( $\times 4)$; B, with $C$. borneensis ants collecting them $(\times 6)$.

transitional species, however, food bodies are produced later, e.g. on stipules of $M$. hosei on average at a height of about $1 \mathrm{~m}(\mathcal{N}=105)$, although a few food bodies are produced earlier, on leaf surfaces from the seventh leaf on. In this species, ant colonization as a rule does not take place on plants smaller than $1 \mathrm{~m}$. 


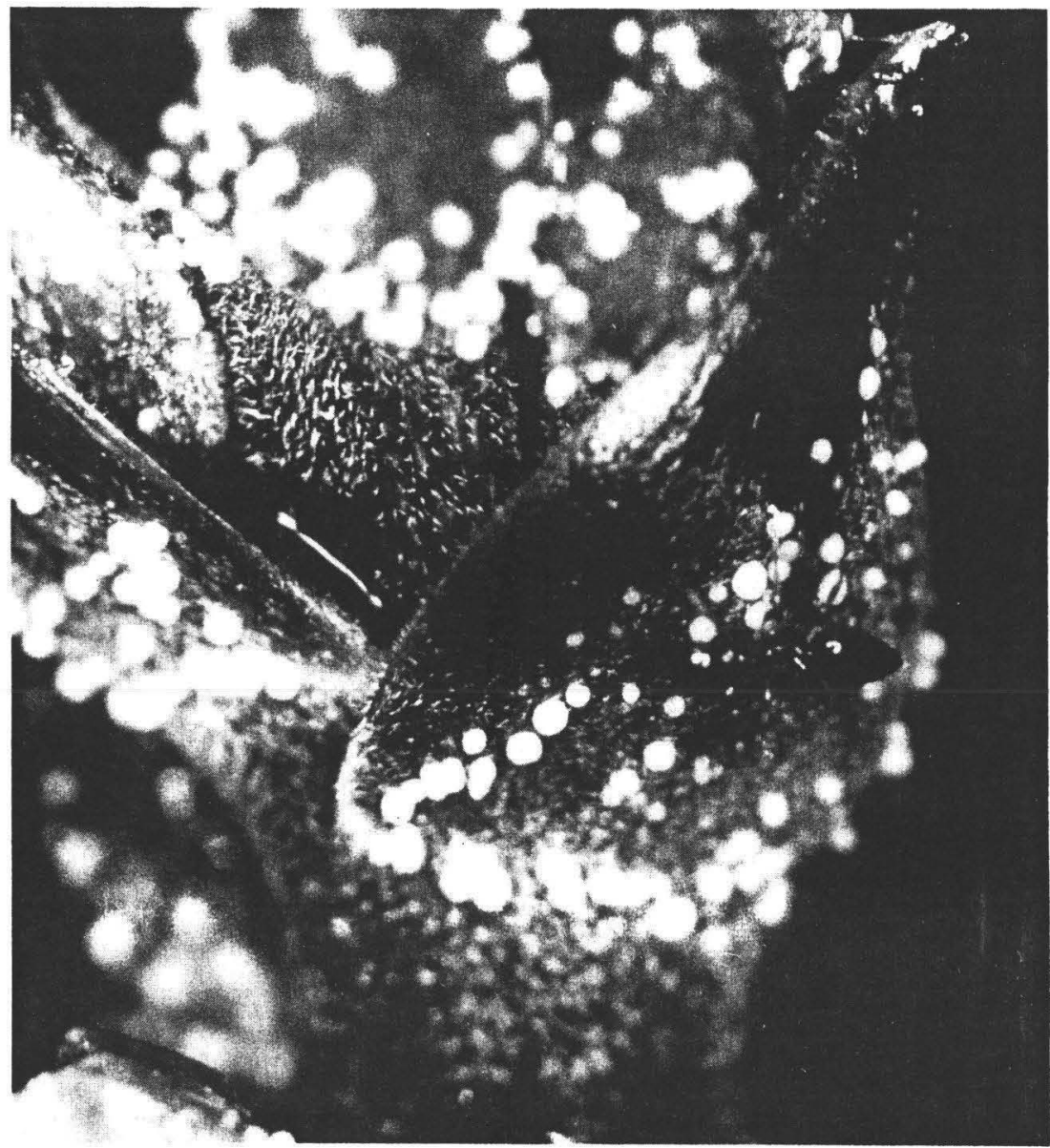

Figure 4 . Food bodies on the bracts of female flowers of $M$. triloba $(\times 7)$

In the greenhouse, myrmecophytic species also produced small food bodies scattered over leaf surface and stem. In the field, this was seen only after exclusion of ants, e.g. by means of sticky rings (with tanglefoot glue) around the stem.

The occurrence of food bodies is not restricted to intermittent plant growth seasons so ants are permanently supplied with food. Since Macaranga trees grow rapidly, many leaves and stipules, on which food bodies develop, are produced continuously. In the field, unbranched $M$. triloba saplings produced on average three new leaves per month.

\section{Non-myrmecophylic Macaranga species}

Non-myrmecophytic species also produced food bodies in the greenhouse (Fig. 5). However, investigation of food bodies in the field was a problem in these 


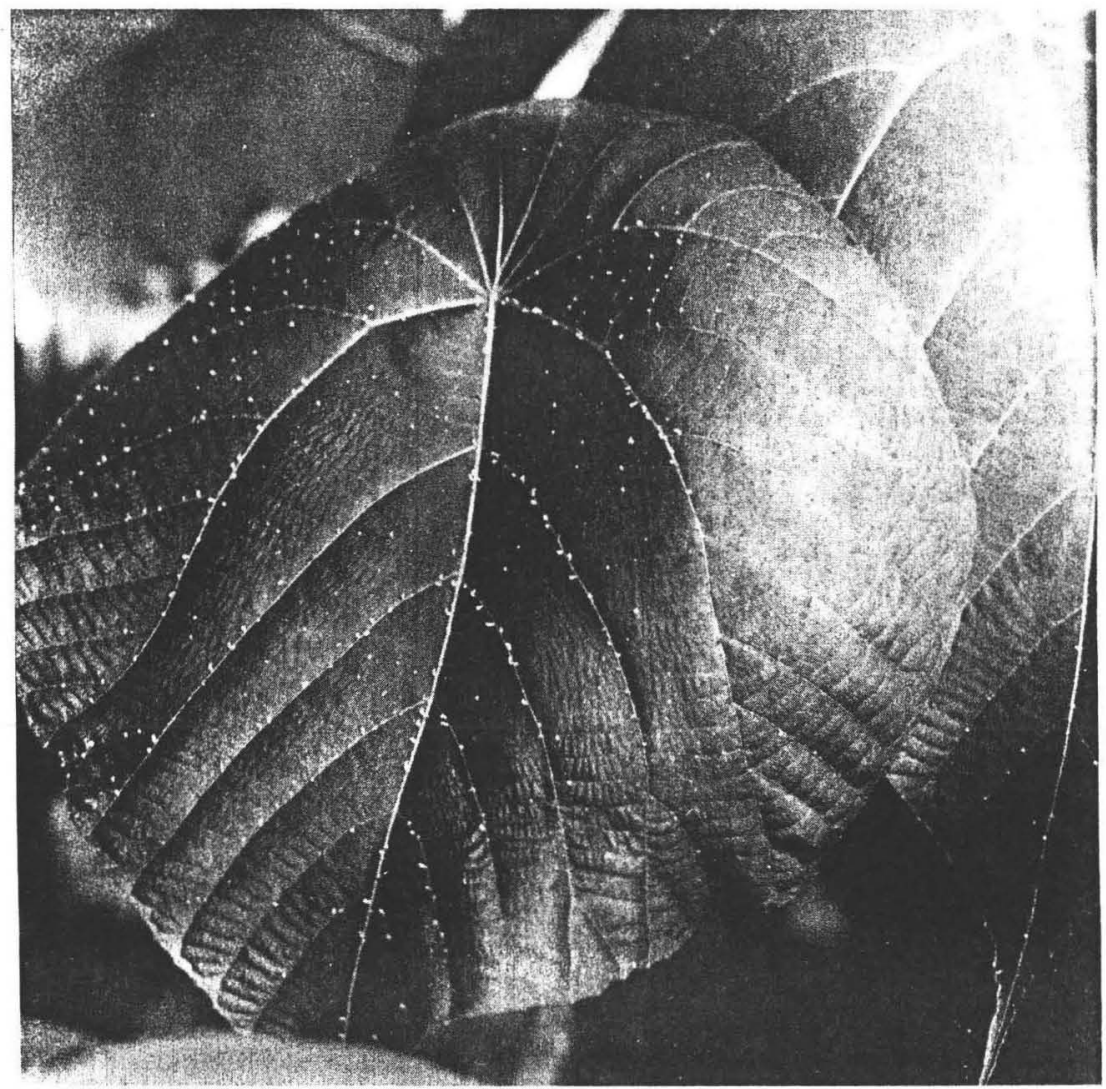

Figure 5. Food bodies on the upper surface of leaves of non-myrmecophytic .11. tanarius (one-third of natural size).

species because they were not concentrated on protected plant parts: Instead, food bodies were scattered over leaf surfaces along veins and on stems. These are not easily seen in the field. Only after very thorough investigations were some found in parts of the plants less accessible to ants, e.g. on the stem under ver! narrow stipules which hindered access of all but very small ants. However, when ant access was excluded (e.g. by means of sticky rings with tanglefoot), food bod! production became obvious in the field, with many food bodies occurring on the plant surface. Most of the non-myrmecophytes do not possess conspicuous and persistent stipules but drop them soon after a leaf has fully grown. Those which persist (in M. gigantea (Rchb. fil. \& Zoll.) M. A., M. diepenhorstii (Mi(p.) Muell. Arg., M. recurvata Gage) are usually not recurved as is the case in the myrmecophytic species of Macaranga. The only exceptions are M. quadricornis Ridley (but here the stipules are wide open) and $M$. indica Wight, in which the? are narrow and twisted, and the space between them and the stem is difficult for ants to reach (Fig. 6). In the field, however, we mostly found food bodies along main leaf veins on the lower leaf surface (see Table 1). Although non- 

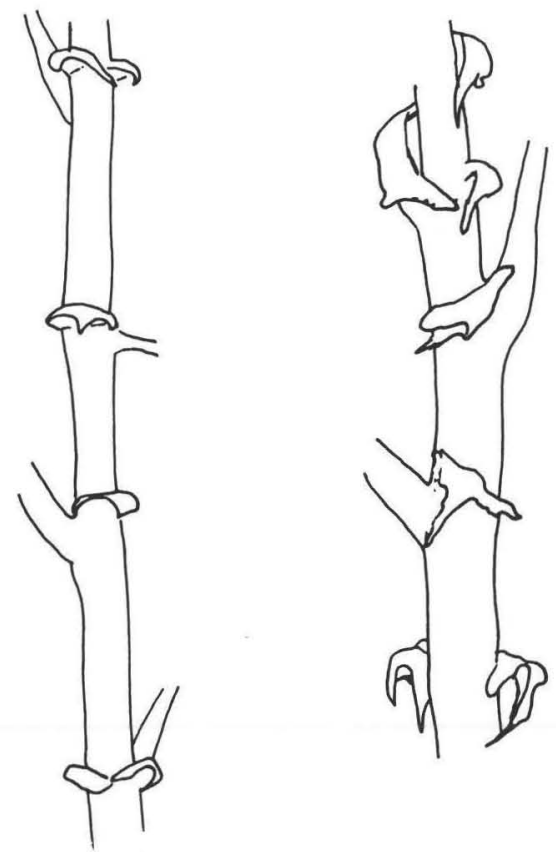

Figure 6. Stipules of $M$. quadricornis (left) and $M$. indica (two-thirds of natural size).

myrmecophytic Macaranga spp. developed food bodies, the amount produced differed between them (Table 2).

On $M$. tanarius saplings many food bodies are produced at the base of the stem. Numbers decrease higher up the stem but rise again at the level of the leaf insertions. Leaf petioles are also densely covered with food bodies.

To date, we have not thoroughly investigated food body production in the section Pseudo-Rottlera, which comprises species occurring in primary forest. Observations on $M$. lowii indicate that food body production also occurs in this section. Pseudo-Rottlera is closely related to and morphologically intermediate between Macaranga and the genus Mallotus, which also produces food bodies (Rouppert, 1926), thus indicating a wider distribution of this attribute within the family Euphorbiaceae. On two Mallotus paniculatus cultivated in the greenhouse food bodies were produced on both leaf surfaces along the veins (upper leaf surface average of 50 food bodies, lower side 10). They were collected from the plant by Plagiolepis sp., an ant living in the greenhouse. On Mallotus paniculatus and Mallotus macrostachys food body production was rarely conspicuous in the field.

In neither the field nor the laboratory did C. borneensis ants accept food bodies of Macaranga tanarius or other non-myrmecophytes offered to them on the leaves of their host plants: they preferred food bodies from myrmecophytic Macaranga species. Food bodies from the neotropical ant-plant Cecropia (Cecropiaceae) were likewise rejected (28:2).

In the field, food bodies of non-myrmecophytic Macaranga are probably 
collected by various ants: A total of 26 species of 14 genera were found on the leaves of non-myrmecophytic Macaranga species (Fiala \& Maschwitz, 1991). Only two of these were not interested in the food bodies Polyrachis sp. and Cladomyrma sp.). Many of these ants were also found on other species in the vicinity. There was no evidence for any species-specific relationship between non-myrmecophytic Macaranga and the visiting ants.

Preliminary tests on food body contents were carried out on $M$. tanarius. $M$. Iriloba and $M$. hosei (two plants cach) representing respectively nonmyrmecophyte, myrmecophyte and transitional species. Food bodies containcd about $6-10^{\circ}$ lipids, $6-12^{\circ}$, sugars and $40-60^{\circ}$, water (percentage of wet tissue weight). The average percentage of carbohydrates appeared to be higher in the non-myrmecophytic species $\left(1012^{\circ}\right.$ o versus, $\left.8^{\circ}{ }_{10}\right)$. The amount of protein varied from $5-3 \%$ in $M$. triloba and $M$. hosei to only about $1.5 \%$ in $M$. tanarius (H. Grunsky, personal communication.)

\section{DISCUSSION}

\section{Contents of food bodies}

Food offered by plants to potential ant visitors is likely to be a predisposition for the evolution of myrmecophytism. Extrafloral nectaries have been cited as a feature of myrmecophytes (Janzen, 1966; Wilson, 1971). Production of food bodies in addition to nectar from EFN provides a more complete diet for ants than nectar alone. The larger amounts of lipids and/or proteins in food bodies can offer a dietary complement to nectar or honeydew obtained from homopterans (Beattie, 1985).

Food bodies of Macaranga contain large amounts of lipids (Rickson, 1980) and amino acids. Of the ten amino acids considered to be essential for insects by Hagen et al. (1984) only two have not been found so far in Macaranga food bodies (Rickson, personal communication). In addition, food bodies provide carbohydrates and are therefore an energy-rich and easily accessible food source, which, being solid, has one more advantage: contrary to the openly secreted nectar they are aseptically packed and therefore a longer-lasting food source.

Little is known about differences in nutrient content of food bodies from myrmecophytic and non-myrmecophytic species. Comparison of our data and those of Rickson's analysis for M. triloba (personal communication), showed rather high variation, probably due to differing methods. However, the results demonstrated that all important nutrients occur. The preliminary result of a higher protein and lower carbohydrate content in a myrmecophytic species compared to the non-myrmecophytic $M$. tanarius is especially interesting. Food bodies of $M$. tanarius were collected by various ant species, but not all ants visiting M.tanarius leaves accepted them. Davidson et al. (1991) also report rejection of food bodies by generalized foragers on Cecropia plants, so there may exist a dietary adaptation of ants to plant food.

\section{Production rates}

We found that the non-myrmecophytic Macaranga species studied also produced food bodies. Contrary to the observations of Baker (1934), Ong (1978) 
and Rickson (1980), we have noted scattered food bodies occurring on nonmyrmecophytic Macaranga species. Recording food body production in the field is difficult because they are continuously harvested by a wide range of ant species. It is likely, therefore, that substantial food body production may occur in all non-myrmecophytic Macaranga species.

The numbers of food bodies produced differed between non-myrmeccophytic and myrmecophytic species and may indicate degrees of specialization. Further differences in production rates were found even among myrmecophytic species, with species of the pruinosa-group producing fewer food bodies than those of section Pachystemon sensu stricto. Plants with enhanced food body production may support larger ant colonies which means a better protection for the host plants. This may be one reason why on equally tall plants of $M$. triloba and $M$. hosei relatively smaller colonies are found on the latter (personal observation).

\section{Localization}

In some myrmecophytic Macaranga species food body production takes place in the protected space under recurved stipules, in others ('transitionals': M. hosei, $M$. pruinosa) food bodies develop openly on the stipule surface. The latter situation has two consequences: food bodies are not sheltered against unfavourable weather and are easily accessible to all ant species. This could lead to stronger competition between inhabiting ants and visiting ant species.

Non-myrmecophytic Macaranga species usually lack sheltered food body production sites. Macarangus tanarius produces the greatest number of food bodies of all non-myrmecophytes investigated. In this species the pattern of food body distribution (many food bodies produced at the base of the stem) gives the impression that they serve to attract ground foraging ants to climb up the plants.

\section{Function}

EFN in non-myrmecophytic Macaranga species are visited by many different ant species, which probably also collect food bodies (Fiala, 1988; Fiala \& Maschwitz, 1991). The specificity of the interaction is very low, and the presence of ants on the plants is only of short-duration. A possible protective role of the visiting ants has been tested for three non-myrmecophytic Macaranga in New Guinea but such a function was not clearly supported by the evidence (Whalen \& Mackay, 1988).

In many studies the protective role of EFN through ant attraction has been investigated (review e.g. Beattie, 1985; Huxley, 1986; Keeler, 1989), but almost no information exists on the distinct effects of food bodies. Despite the production of EFN and food bodies some uninhabited Macaranga species had a higher amount of herbivore damage and vine cover than myrmecophytic species (Fiala et al., 1989, 1991). However, after removal of EFN and food bodies the non-myrmecophytes were subject to even stronger herbivore damage. There appeared to be less herbivore damage on plants which had only food bodies removed than those in which EFN were selectively extirpated. This may indicate that these food rewards are differentially used by several ant species with different protective value for the plants. 
- We found dense food body protection also on the floral bracts of female flowers of M. triloba (myrmecophyte). These bracts were visited by the inhabiting C. borneensis ants which may protect the flowers from herbivorous insects. Male flowers of myrmecophytic $M$. hullettii plants, for example, which did not produce food bodies, were frequently damaged by geometrid caterpillars (personal observation).

\section{Food bodies and the evolution of myrmecophytism}

O'Dowd (1982) suggested that integration of two food resources (EFN and food bodies) should increase the dependence of associated ants on the plants. Schupp \& Feener (1991) found no correlation between food body production and presence of EFN in their extensive survey of these ant-associated features among Panamanian forest plants. In Macaranga and the related genus Mallolus EFN and food bodies occur together at on the generic level. There is, however, no indication of prevalence of food bodies in Macaranga species which in addition have EFN. On the contrary, food bodies are best developed in myrmecophytic species which have reduced EFN, but offer nesting space. This is in agreement with O'Dowd's finding that all three resources-food bodies, EFN and domatia (structures providing nesting space) - rarely occur together, but food bodies either with EFN or domatia do.

Both EFN and food bodies are widespread in Macaranga and were important prerequisites for the evolution of association with ants. However, since both still occur simultaneously on non-myrmecophytes, although EFN have been reduced and food body production was increased in myrmecophytes, the presence of these two kinds of food rewards alone does not explain myrmecophytism. The availability of protected nest sites on the host plant may have been the decisive additional factor which led to obligatory associations.

Several well known obligate myrmecophytes exist in other genera which offer not EFN but food bodies, for instance Cecropia, Piper (review e.g. Huxley, 1986), where ants may tend homopterans. The dominating ant partner C. borneensis of the myrmecophytic Macaranga species seems to depend rather strongly on food bodies but also lives in close relationship with scale insects through which the ants obtain plant sap. Although ants may not necessarily require additional food from the host plant, food bodies may be an important feature attracting the ants to patrol the leaf surfaces, thus increasing ant defence against herbivory. For the plants it is important that ants do not simply visit them temporarily for foraging but stay permanently. Therefore structures increasing ant fidelity, such as nesting space, should be selected for. Domatia (or suitable preadaptations for nesting space) should be an important attribute enhancing the fidelity of the ant association and facilitating the cultivation of scale insects.

McKey (1989) discussed the significance of various preadaptations for symbiotic ant-plant systems and emphasized the possible role of domatia. W' believe that evolution of myrmecophytic species in the genus Macaranga was also based on morphological host plant traits which could serve as nesting space for ants. Studies of stem morphology showed that hollow structures or predispositions for cavities seem to be a very important feature for obligate interactions with ants in this genus (Fiala \& Maschwitz, 1992). 
Ant-attracting food bodies have certainly played a role in evolving a closer relationship with ants. Despite this, many Macaranga species have not evolved more than a facultative interaction with ants. The localization and increased production of food bodies on specific structures is found only in Macaranga species with domatia. We suggest that only Macaranga species with predispositions for domatia developed into obligate myrmecophytes. Ant inhabitation certainly offers advantages for the Macaranga plants, especially concerning plant competition, e.g. vines, which are abundant in habitats where Macaranga grows (Fiala et al., 1989). Species without ants have developed other survival strategies, and their competitive ability can be achieved by different habitat requirements as well as by different types of growth (Fiala et al., 1991). However, myrmecophytic Macaranga species belong to those who have most successfully made the transition from primary forest to secondary habitats. The association with ants is an important factor allowing Macaranga plants to grow at sites of strongest competition.

\section{ACKNOWLEDGEMENTS}

The director of the Forest Research Institute Malaysia (FRIM) Dato Dr Salleh Mohd. Nor generously gave permission to work at FRIM and its field stations. We thank Mr K. M. Kochummen and Mr L. G. Saw for their support at the herbarium of FRIM. The Department of Zoology, Universiti Malaya granted permission to use their field station in Ulu Gombak. We are indebted to W. Killmann (GTZ) for logistic support. Dr J. Longino kindly checked the Crematogaster specimens. M. Ruppel helped with the SEM studies. We thank Prof. F. Rickson for information on unpublished work, Prof. D. O'Dowd, Dr P. E. Brandham, Dr A.J. Helbig, and an anonymous referee for valuable comments on the manuscript. This study was financially supported by the Deutsche Forschungsgemeinschaft (DFG) and by research grants of the DAAD (German Academic Exhange Service) to B. F.

\section{REFERENCES}

BAKER, J. A., 1934. Notes on the biology of Macaranga spp. Garden's Bulletin Straits Settlements, 8: 63-68. BEATTIE, A. J., 1985. The Evolutionary Ecology of Ant-plant mulualisms. Cambridge: Cambridge University Press. BLCKLEY, R. C. (Ed.), 1982. Ant-plant interactions in Australia. The Hague: W. Junk Publishers.

DAVIDSON, D. W., FOSTER, R. B., SNELLING, R. R. \& LOZADA, P. W., 1991. Variable composition of some tropical ant-plant symbioses. In P. W. Price $e$ al. (Eds), Plant-Animal Interactions: Evolutionary Ecology in Tropical and Temperate Regions: 145-162. New York: J. Wiley \& Sons.

FIALA, B., 1988. Biologie, Funktion und Etolution eines malaysischen . Mrrmekophytiesystems: Die Assoziation zon Crematogaster borneensis (Form.: Myrmicinae) mit Bäumen der Gattung Macaranga (Euphorbiaceae). Unpublished $\mathrm{PhD}$, thesis of the University of Frankfurt.

FIALA, B. \& MASCHWITZ, U., 1990. Studies on the South East Asian ant-plant association Crematogaster borneensis/Macaranga: Adaptations of the ant partner. Insectes Sociaux, 37(3): 212-231.

FIALA, B. \& MASCHWIIZ, U., 1991. Extrafloral nectaries in the genus Macaranga (Euphorbiaceae) in Malaysia: comparative studies of their possible significance as predispositions for myrmecophytism. Biological Journal of the Iinnean Societr, 44: 287-307.

FIALA, B. \& MASCHWITZ, U., 1992. Domatia as most important adaptations in the evolution of myrmecophytes in the palcotropical tree genus Macaranga (Euphorbiaceae). Plant Systematics and Evolution, 180: $53-64$.

FIALA, B., MASCHWITZ, L. \& THO, Y. P., 1991. The association between Macaranga and ants in South East Asia. In D. F. Cutler \& C. R. Huxley (Eds), Interactions Between Ants and Plants: 263-270. Oxford: Oxford University Press. 


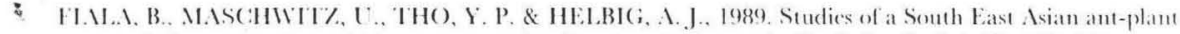

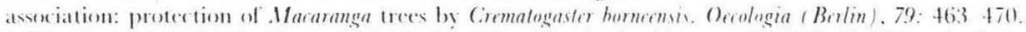

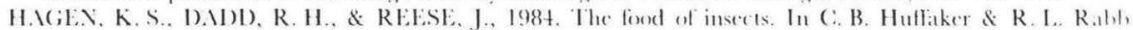
Fids, Etonlagical Entomology: 79 112. New York: Wiles.

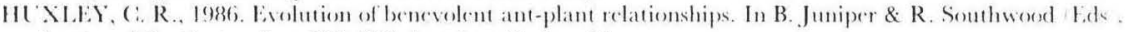
Insects and the plant surface: 257 282. London: E. Armold.

JANZEN, 1). H., 1966. (ocvolution of mutualism between ants and acacias in (ientral America. Erolution, 20): 249275

KEELER, K. H., 1989. Ant-plant interactions. In W. G. Abrahamson, Plant-animal Interaitions: 207-242. New York: MacGraw-Hill.

McKEY, D., 1989. Interactions between ants and leguminous plants. In C. H. Stirton \& J. L. Zarucchi (Lids, Adiances in Legume Biology: 673-718. Monographs in Systematical Botany, 29. St. Louis: Missouri Botanical Garden.

MOKRASCH, L. C., 1954. Analysis of hexose phosphates and sugars with the anthrone reagent. Journal of Biological Chemistry, 208: 5559.

()'D()WD, D. J., 1982. Pearl bodies as ant food: an ceological role for some leaf emergenees of tropical plants. Bistropica, 14: $40-49$.

ONG, S. L., 1978. Ecology of the ant-association in Macaranga triloba. C'npublished Ph.D. thesis of the Universits of Malaya, Kuala Lumpur.

PENZIG; O., 1892. Uber die Perldrüsen des Winstocks und anderer Pflanzen. Alti del Comgresso Botammo Internazionale (Genovia): 237-245.

R.ACIBORSKI, M., 1898. Biologische Mitteilungen aus Jata. Flora. 85. 325367.

RACIBORSKI, M., 1900. Uber myrmekophile Pflanzen. Flora, 87: 3845.

RICKSON, F. R., 1980. Developmental anatomy and ultrastructure of the ant-food bodies Becearian bedies

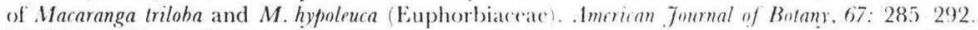

RICKSON, F. R., \& RISCH, S. J., 1984. Anatomical and ultrastruetural aspects of the ant-food cell of Pryer senocladum C.DC. (Piperaceac). American Journal of Botany. 71: 1268 1274.

ROUPPER'T, C., 1926. Observations sur les perlules de diverses especes de phanerogames. Bulletime du . 1fureum dHistoire Naturelle Paris, 32: 102-107.

SCHUPP, E. W. \& FEENER, D. H., 1991. Phylogeny, lifeform and hibitat dependence of ant-defended plants in a Panamanian forest. In D. F. Cutler \& C. R. Huxley Eds). Interatiums Between Ants and Plants: 175197. Oxford: Oxford University Press.

WHALEN, M.A., \& MACKAY, D. A., 1988. Patterns of ant and herbivore activity on five understory cuphorbiaceous saplings in submontane Papua New Guincat. Biotropica, 20(7):294 300.

WHITMORE, T. C., 1967. Studies in Macaranga, an easy genus of Malavan wayside trees. Malavan . Matue Journal, 20: 89-99.

WHITMORE, T. C., 1973. Tree fora of Malaya. Kuala Lumpur, London: Longman.

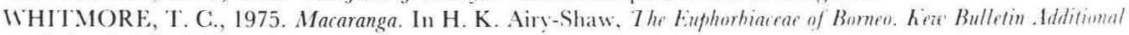
Series, $4: 140-159$.

WHITMORE, T. (., 1982. Macaranga. In H. K. Airy-Shaw, The Euphorbiacear of Sumatra. Kene Bulletim. 36: $312-323$.

WILSON, E. O., 1971. The Insect Societies. Cambridge, Mass.: Belknap Press of Harvard Lniversity Press. 